\title{
Successful Sermonic Communication in Multi-Cultural African Contexts: The Cultural Intelligence Imperative
}

\author{
Olusanya Kehinde Olukayode* \\ Lecture Nigerian Baptist Theological Seminary Ogbomoso, P.O.Box 4008, Ogbomoso, Oyo State, Nigeria \\ *Corresponding Author \\ Kehinde Olusanya
}

\section{Article History}

Received: 31.08.2019

Accepted: 13.09 .2019

Published: 23.09.2019

\begin{abstract}
This work Successful Sermonic Communication in Multi-Cultural African Contexts: The Cultural Intelligence Imperative is motivated by the increase in multi-cultural churches springing up in Africa. The network of globalization, secularization, modernization and postmodernism corporate to escalate this phenomenon in the African context, as movements from the rule areas to urban centres become more increasing unstoppable. The changing face of church congregants propels Homiletics to seek means and methods of ensuring successful sermonic communication in these highbred congregations. The interplay between culture and communication constitute a challenge to effective preaching in multi-cultural contexts in Africa, the writer therefore proposed 'cultural intelligence' as a resource for the challenge. Using the historical and descriptive research methods the writer exposes the cultural intelligence components as they serve as panacea for the described problem. The work reveals that successful sermonic communication is achievable in multi-cultural contexts as preachers develop cultural intelligence.
\end{abstract}

Keywords: Culture, Intelligence, Multi-cultural, Communication, Sermon.

\section{INTRODUCTION}

There is no arguing that the world is culturally diverse. The number of languages spoken in the world for instance is constantly influx for the reason that new discoveries continue to emerge in reference to the languages of the world. Stephen Anderson posits that an estimated 6,909 languages exists in the contemporary world. This language plurality has missiological and homiletical implications. Missiologically, deliberate and strategic efforts should be made to reach people beyond cultural boundaries. Accomplishing this task would require a good understanding of the interplay between culture, religion and communication. The homiletical implications of the multi-cultural nature of the world are diverse. This is because several factors would be considered in biblical communication among different cultures.

The implication of the above therefore, is that biblical communication should be put in context of the culture of listeners, with adequate understanding of the culture of the bible. This is easier when a preacher is dealing with only one cultural setting, however, when the context is multi-cultural, preachers would be required to possess communication expertise in a multi-dimensional level. This paper intends to investigate the necessity for cultural intelligence in sermonic communication in a multi-cultural context. This paper assumes that cultural intelligence is an imperative for successful sermonic communication in culturally diverse contexts. In pursuance of this thesis, the writer will consider conceptualizing cultural intelligence, understanding successful sermonic communication, the interplay between culture and communication, and the nexus between cultural intelligence and successful sermonic communication.

\section{Conceptualizing Cultural Intelligence}

There are no people without a cultural identity. Paul S. Fiddes avers that the concept of faith is not the mere construction of words, but it is embodied in the life and practices of human communities. Again, it is impossible for these communities to exist without a collective understanding of this embodiment. This is what translates to cultural identity according to Fiddes[1]. David J. Hesselgrave and Edward Rommen explain that the primary target of missionaries in communication should be to present the supra-culture message of the gospel in culturally significant forms [2]. This therefore means that the cultural identity of people cannot be ignored in the communication of the gospel. This becomes important because of the growing cultural diversity in the contemporary church. E.V Hill explains that the diversity of the cultural background of congregants bequests preachers the responsibility to discover methods for

Copyright @ 2019: This is an open-access article distributed under the terms of the Creative Commons Attribution license which permits unrestricted use, distribution, and reproduction in any medium for non commercial use (NonCommercial, or CC-BY-NC) provided the original author and source are credited. 
effectively presenting the gospel in such a way that it is acceptable within the cultural worldview of congregants [3]. The complexities involved in balancing biblical communication and multi-cultural identities in congregations, paved way for divergent ideologies and recommendations of which cultural intelligence is a part. Matthew D. Kim argues that cultural intelligence is an invention of people in the business world in order to maximize opportunities to interact with customers outside the businesses cultural stereotype [4].

Cultural intelligence is a concept of recent interest for scholars in the areas of communication, business, leadership, and other fields requiring cross-cultural relations. David Livermore explains that the concept was developed deliberately because of the need to succeed in the face of globalization. Livermore explicates that succeeding in a highly globalized world necessitates the capacity to acclimatize in a multiplicity of cultural circumstances. This necessity becomes the background for the development of the concept. Livermore defines cultural intelligence as an individual's capacity to efficiently function across a diversity of cultural perspectives [5]. Livermore asserts:

$\mathrm{CQ}$ or cultural intelligence is the capability to function effectively in a variety of cultural contexts, including national, ethnic, organizational, and generational. It's a whole new way of approaching the age-old topics of cultural sensitivity, racism, and cross-border effectiveness. And it will open up a whole new world of possibilities.

Livermore's position is that cultural intelligence is required within all fields that possess the interplay of communication and culture. Livermore also notes that generational cultural contexts require the use of cultural intelligence. This is important for Missiologists and Homileticians because of the necessity of ministering beyond generational lines.

Similarly, Soon Ang and Linn Van Dyne explain cultural intelligence as the competence capacity to function and cope effectively in culturally diverse settings [6]. The growing inter-cultural necessities in the area of business and others, makes a demand on those who participate in such endeavours to possess multi-cultural communicative acumen. The ability to survive effectively, and proficiently handle inter-relations within different cultural milieu is what is referred to as cultural intelligence. According to $P$. Christopher Earley and Soon Ang, Cultural intelligence is largely located in literatures of organizational and management theory, this multidisciplinary concept is an individual intelligence difference that explicates the rationale responsible for individual's ability to cope successfully in dissimilar cultures [7]. Cultural intelligence provides explanations for the incongruities that exist between managers being competent in their own cultural context, but less competent in other cultural contexts [5]. It is the capacity to perform excellently in circumstances characterized by cultural diversity.

David Livermore suggests that cultural intelligence $(C Q)$ is composition of four major capabilities. These capabilities as listed by Livermore are: CQ drive (motivation), CQ Knowledge (cognitive), CQ Strategy (Meta-cognitive), and CQ Action (behavioural)[9]. The diagram below represents a pictorial representation of the four dimensional model of cultural intelligence as proposed by Livermore [10].

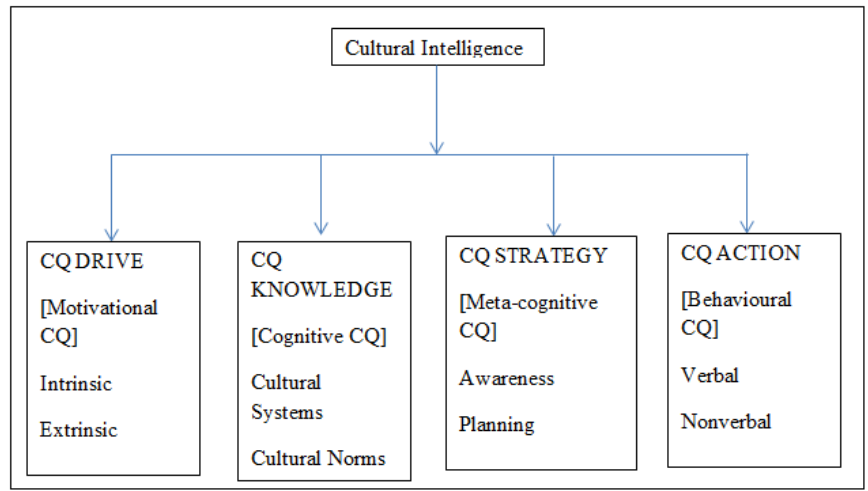

Fig-2.1: Four Dimensional Model of Cultural Intelligence

\section{CQ DRIVE (MOTIVATIONAL)}

This refers to the interest and confidence in functioning effectively in culturally diverse settings. The necessity for a personal drive to successfully participate in multicultural contexts, regardless of the obvious challenges involved is imperative for developing cultural intelligence [11]. Matthew D. Kim explains that $C Q$ drive is the inner longing for a proper and beneficial understanding of the similarities and dissimilarities of culture [12]. This particular $C Q$ quotient is based on individual willingness to learn the diverse variations in cultures and how such variations affect social interaction with other cultures. Motivational CQ also represents the capacity to devote specific attention to learning across cultures [13].

\section{CQ KNOWLEDGE (COGNITIVE)}

This refers to the understanding individuals possess on the differences and similarities of cultures. The emphasis in this type of cultural intelligence is not becoming an expert on every culture, but, possessing a high level cognition of core cultural dissimilarities 
and the impact such differences have social interactions[14]. This $C Q$ dimension is based on the knowledge of practices, standards, and customs used in different cultural contexts, acquired through education and/or practice [15].

\section{CQ STRATEGY (METACOGNITIVE)}

This is how participants in a culturally diverse context make sense of personal thought process, and the thought process of others as it affects experience. This type of cultural intelligence assists participants to plan in the light of cultural diversity [16]. Metacognitive $C Q$ refers to an individual's cultural perception and the cognizance of cultural signals that prop-up in the course of intercultural communication [17].

\section{CQ ACTION (BEHAVIORAL)}

This is the ability of participants in a culturally diverse setting to adapt behaviour to fit appropriate response in different cultural contexts [18]. This dimension of cultural intelligence refers to the individual capacity to demonstrate appropriate verbal and nonverbal actions in the course of intercultural communication [19].

The combination of the above mentioned capabilities makeup the cultural intelligence quotient. This suggests that rating individual cultural intelligence requires measuring the above capabilities in different measures in the interactions of participants in multicultural contexts. Each capability should be evident, though, in different proportions, in the interactions of participants (in a multicultural context) that could be termed culturally intelligent.

\section{Understanding Successful Sermonic Communication}

The term sermonic communication basically refers to the preaching of an idea embedded in a sermon. This reference the homiletical understanding that until a sermon is communicated to an audience, preaching has not been carried out. The sermon is no stranger in ecclesiological parlance; it is regarded as central to Christian worship. The concept has been defined by diverse authors in divergent ways. Donald Cantrell defines a sermon as the finished product of the preparation process of preaching, which the man of God takes to the pulpit to deliver to the congregation. Cantrell refers to a sermon as a "serious talk about Jesus [20]." This underscores the vocal nature of a sermon. Cantrell's definition explicates the fact that a sermon passes through several process before it can become a whole. F.A.C Mantello and A. C Rigg view a sermon as a religious discourse, delivered to a specific audience by a preacher who provides instructions on matters of faith and morals [21]. The duo also understand a sermon to be vocal in nature, they however include in their definition the fact that a sermon is carried out in the religious setting, it always has a specific audience, and it is instructional in nature.

One definition of the sermon that could be regarded as renowned is the definition by Phelps in his work "The Theory of Preaching," this definition states: "A sermon is an oral address to the popular mind upon religious truth as contained in the Scriptures, and elaborately treated with a view to persuasion [22]." Each phrase that makes up this profound definition can be viewed as important. T.H Scambler suggestively asserts that the most important phrases in Phelps' definition are the references to the Scriptures and to persuasion. This suggests that an address will not be a sermon except it deals specifically with biblical truth, with the end of affecting the hearts and lives of the listeners [23]. The other important part of Phelps' definition mentions the fact that the purpose of the sermon is persuasion. There is the possibility to consider persuasion as a concept that is more appropriate in advertising, marketing and other business related concerns as opposed to religious communication. David Larson notes that persuasion is not new to the human race. Larson records the negative attitudes of philosophers like Plato and Socrates, identifying persuasion as flattery [24]. Larson however emphasizes that despite the negative mentality against persuasion as a concept the sermonic discourse that does not seek to persuade is not preaching et al. [25] Fred R. Lybrand similarly explains that some words used for preaching in the Greek, gives an impression of persuasion. The first word is kerusso which carries a meaning of authoritative proclamation that expects a response from listeners. The other word is peitho, which means to persuade with kind words, it also means to motivate another person to receive a belief [26]. Lybrand however cautions that the kind of persuasion required in sermonic communication is not manipulative; it does not involve marketing gimmicks and unnecessary emotion stimulating illusions [27].

Alan John Ehler provides seven (7) variables that are necessary to measure the effectiveness of a sermon. According to Ehler for a sermon to be referred to as effective it should have the following elements: biblical, Christ-centred content, relevance to listener's context, persuasive appeal, engaging illustrations, dynamic delivery, an authentic preacher, and Holy Spirit empowerment [28]. These elements represent the ideal requirements for effective sermonic communication. The first requirement biblical, Christcentred content, underscores the centrality of the word of God in sermonic discourses. The understanding of being biblical is that effective sermons should be based on the bible. In support of this understanding, Sidney Greidanus explains that the foremost test of the validity and effectiveness of a sermon is the test of its biblical orientation [29]. Greidanus posits that no greater measure exists for the test of effectiveness of a sermon, than its consistency with scriptures. This is because the bible is the criterion for preaching; an effective sermon should therefore correctly interpret the normative infallible word of God [30]. Similarly, Donald R. Sunujian explicates that the bible is the voice of God through all ages; the preacher should therefore accurately interpret the bible and present it in a manner meaningful to contemporary listeners [31]. 
The second part of the first requirement is the Christocentric nature of effective sermonic discourses. Greidanus posits that effective sermonic communication should be anti-anthropocentric preaching. The preaching of the word of God should not be centred on the people in the bible or the contemporary listeners, it is should be centred on Christ. Greidanus however argues that the attempt to be Christocentric could lead to faulty interpretations and homiletical pitfalls like allegorising and creating arbitrary typologies [32] Greidanus also argues that Christo-centrism in preaching should not be limited to the person of Christ so as not to be guilty of what Greidanus refers to as "Jesus-centrism". He therefore notes that to be Christocentric in preaching should be considered as broad as to be theocentric [33]. Sermonic communication that will be effective should balance successfully in its content the concepts of being biblical and Christocentric.

The second recommended criterion is relevance to listener's context. Similarly to every kind of interpersonal communication, sermonic communication involves transmitting biblical information from the preacher to a congregation. The relevance of the information received by the congregation determines to a large extent the effectiveness of the sermon preached. David M. Brown illustrates this reality arguing from the perspective of biblical story telling. Brown avers that the contextualization of a biblical story is necessary because every story is influenced by many factors in order to draw meaning. Therefore, when a story is put in the context of the listener, there is a possibility of affecting the listener's paradigm and influencing the way listeners perceive the communicated truth [34]. John McClure et al. explain the need to consider congregational context and its influence.

On listeners' sermonic perception. This is so because preaching does not take place in a vacuum, interplay exists between the sermon preached, the people hearing it and the cultural milieu within which it takes place [35].

The third criterion, persuasive appeal, deals with the preacher's ability to deliberately to convince listeners of the validity of the sermon. There is the possibility to consider persuasion as a concept that is more appropriate in advertising, marketing and other business related concerns as opposed to religious communication. David Larson notes that persuasion is not new to the human race. Larson records the negative attitudes of philosophers like Plato and Socrates, identifying persuasion as flattery [36]. Larson however emphasizes that despite the negative mentality against persuasion as a concept the sermonic discourse that does not seek to persuade is not preaching at all[37]. Fred R. Lybrand similarly explains that some words used for preaching in the Greek, gives an impression of persuasion. The first word is kerusso which carries a meaning of authoritative proclamation that expects a response from listeners. The other word is peitho, which means to persuade with kind words, it also means to motivate another person to receive a belief [38]. Lybrand however cautions that the kind of persuasion required in sermonic communication is not manipulative; it does not involve marketing gimmicks and unnecessary emotion stimulating illusions [39].

The forth criterion is the need to engage illustrations in sermonic communication. D. Martin Lloyd Jones asserts that illustrations are employed in sermons to make truth clearer. Preachers should ensure that illustrations do not over shadow the word of God; sermons without illustrations may appear like teaching mathematics without examples [40]. The use of illustrations in preaching should not be at the expense of proper biblical exposition. There are different understandings as to the place of illustrations in sermonic communication. The overuse of illustrations to the extent that illustrations cast shadows on the biblical passage is one extreme understanding of the use of illustrations; another extreme is the complete non-inclusion of illustrations in sermons. Al Fasol explains that a balance in the effective use of illustrations in sermonic communication is necessary [41]. Matthew Mckellar also explains that illustrations should be used for the purpose of clarification, illumination, subordination and specification [42].

The fifth criterion for effective sermonic communication is having a dynamic delivery. The way and manner sermons are delivered affects the overall effectiveness. Alfred P. Gibbs proposed three methods of sermon delivery which are reading, reciting and extemporaneous delivery [43]. Dennis M. Cahill explains that the method of sermon delivery employed should be determined by the genre of the sermon text [44]. Haddon Robinson asserts that the effectiveness of a sermon is affected majorly by two important factors, what is said and how it is said. Robinson posits that a sermon awkwardly delivered arrives dead at birth. Sermon delivery method should be selected with consciousness of the verbal and non-verbal import of the delivery style [45]. There are several factors that are important for consideration is selecting appropriate delivery style, however, the most basic would be the context within which the sermon will be delivered.

The sixth criterion is the fact that for a sermonic process to be effective, the sermon should have an authentic preacher. This basically refers to the ethos of the preacher. It is no longer strange on social media, television, newspapers, magazines, and other media related outlets to find headlines describing the unethical, and sometimes outright immoral behaviour of clergymen. This kind of news sometimes pebbled by ignorant and unreligious people goes a long way to portray the clergy in very bad light. Much can be said of financial misappropriation, sexual immorality, and sometimes to the shock of many on the use of diabolic powers to perform signs and wonders. Olusanya avers that Preaching is persuasive communication; persuasion itself is affected by many things, from the persona of the listeners, the conditions involved in the process of communication, to the communicator's acceptability. The overarching effects of the person of the preacher on the outcome of the communication process cannot be over emphasized [46]

John Broadus a legend in the world of homiletics defined preaching according to Phillips Brooks as "the communication of truth by man to man. It has two essential elements, truth and personality [47]." This definition suggests that in delivering the truth of 
God's word the personality of the messenger is involved. David Larsen explaining the rhetoric of Aristotle states that the personal life of the preacher is gamine for congregational persuasion. The preacher's personality, preparation, and attitudes have significant impact on the sermon the preacher presents [48]. Larsen argues that though the Spirit of God can deliberately use the words of a miscreant or scallywag to achieve a purpose in the life of some individual, yet sermonic communication is inherently practiced with the life and experience of the human communicator as a major influence on the acceptability or otherwise of the word presented [49]. The importance of the character of the preacher as an influence on the acceptability of the sermon is stressed by Larsen in the statement "the preacher of the word is not a salesman or a showman; he is a spokesman! Hence our theology of proclamation must be closely wed to our theology of devotion [50]." This statement accentuates the power of the devotional life of the preacher on the acceptability of the message.

\section{Interplay between Culture and Communication}

Understanding the interplay between culture and communication requires an understanding of what culture and communication means. This is basic, because to understand the interaction between culture and communication, it would be necessary to understand the role human communication plays in that process [51]. The concept communication in its simplest form is the process of sending and receiving information. Communication is however complex, this is because communication is always understood within contexts. Again, because meaning is usually derived, there is the tendency to misunderstand communication because meanings are given to what is communicated based on context and as interpreted within culture. Successful cross-cultural preaching should therefore be abreast with different cultural methods of processing information and cognition [52].

Culture as a concept has been defined in many ways. Boobie Kalman summarizes culture as the way and manner of living of a group of people [53]. Living in this context would refer to how people dress, what they eat, how the speak, their stories, celebrations, art, music, ancestors, writings, and a variety of other elements that make up day to day existing of a people. Paul G. Hiebert explains that culture can be viewed as the combined structure of specific behavioural patterns and ideas, learnt overtime, and that are characteristic of a particular society.

Culture and communication obviously have impact on one another. There is the school of thought that the two concepts are fundamentally the same. Vijai N. Giri suggests that culture affects the styles of communication. The cultural contexts where individuals socialize have influence on the way and manner such individuals communicate, and the way individuals communicate have the potentiality to change culture. Culture avails individuals with patterns of behaviours for specific situations as it also provides standards of measurements for the behaviour of others in the same situation. Advancement in culture directly affects modes, means, and methods within cultural contexts [54].

Social units regardless of whether it's an association, assembly, society, or even organisation all develop their own unique culture over a period of time. Though the defining features or group of features of each culture are distinct, however, cultures have some common functions. There are three specific functions of culture that have particular importance for communication: linking individuals to one another, providing the basis for a common identity, and creating a context for interaction and negotiation among members [55]. Marieke de Mooi using advertising as an illustration for the relationship between communication and culture submits that to understand how advertising works across cultures, it is imperative to learn how communication works. This is because communication styles fluctuate according to culture. Mooi explicates that the closest example of this fluctuation would be the divergence between high-context and low-context communication. Similar to that is the difference that occurs in how people process information and their expectations of the role, purpose, and effect of communication [56].

From the foregoing, it clear that the concepts of culture and communication lean on each other for effective functionality. Culture requires communication to avoid extinction since a significant characteristic of culture is that it is taught. Communication requires culture because it does not exist in a vacuum; it therefore depends on culture to locate its context.

\section{Nexus between Culture Intelligence and Preaching in Multi-cultural Congregations}

Multicultural congregations basically refer to congregations that are multi-tribal and multi-lingual in constituent. These kinds of congregations are made-up of individuals from different cultural backgrounds. Sermonic communication within such a context may specifically prove problematic. In order to address the problematic nature of sermonic communication in such a context, this writer proposes cultural intelligence. David Pederson in Preaching Cross-Culturally avers that an effective cross-cultural preacher should possess the ability of an excellent story teller, should also speak with some level of clarity, sincerity, avoid the gratuitous narration, and also assume that the audience understands [57]. All the afore mentioned would be impossible without cultural intelligence. This accentuates the need for $C Q$ drive; which is the desire to understand the similarities and dissimilarities of culture. Effective sermonic communication in multi-cultural congregations begins from the understanding of the cultural background of parishioners; this will be effectively aided by $C Q$ drive.

The $C Q$ knowledge is also necessary for preachers to measure the extent of their knowledge of the difference between cultures. This is necessary ascertain the level of cultural ignorance on the preachers operate. Matthew D. Kim explains that the $C Q$ knowledge helps to measure: 
What knowledge do we currently possess about various listeners as we prepare to preach to them? For instance, what beliefs or values influence their daily decisions? Are they individualistic (making decisions based on individual preferences) or collectivistic (making decisions according to what's best for a group)? Would they rather spend time with you (as a being-oriented culture) or accomplish something with you (as a doing-oriented culture)? On what do they spend their time and resources? What types of food do your listeners eat, and what do they decline? What cultural values are most highly esteemed in their culture: honesty, hard work, success, age, education, profession, salary, position, or status? What cultural idols obstruct the gospel from taking root in their lives, and more [58]?.

Kim paints a beautiful picture of the display of cultural intelligence in the interaction of Philip and the Ethiopian eunuch in Acts 8:26-39[58]. This succinct explanation of the exchange of ideas, questions, and dialogue between Philip and the Eunuch portrays the necessity for cultural intelligence in a culturally diverse world like today's world. Pederson posits that preachers in cross-culture contexts would require increasing their geopolitical capacity, balance culturally-bound illustrations, beware of humour gaps, be careful to use statistics that are culture sensitive, and be careful to use hermeneutics that are bias culturally. All of these are matters that cultural intelligence can prepare the preacher for.

\section{CONCLUSION}

The world is constantly becoming more culturally diverse. The results of globalization, urbanization, and post-modernistic tendencies have contributed to increased socialization in many parts of the world. This increase in social interactions has become a platform for the expansion of cultural socialization. Increase in social interaction among culturally diverse people has advanced into growth in the development of heterogeneous congregations. Sermonic communication in these kinds of churches requires extra preparation for effectiveness.

This paper discussed how cultural intelligence can serve to make preachers in a culturally diverse context more effective in sermonic communication. The paper explains cultural intelligence as the ability to easily and effectively adapt in different cultures, particularly cultures other than one's own. Different stages of cultural intelligence were identified. The paper points out the interplay between culture and communication identifying the fact that a symbiotic relationship exists between the two concepts. The position of the writer is that effective sermonic communication in multi-cultural congregations requires cultural intelligence.

\section{REFFERENCE}

1. Paul, S. (2012). Fiddes,"Ecclesiology and Ethnography: Two Disciplines, Two worlds?" in Perspectives on Ecclesiology and Ethnography. Paul Ward (ed) (Grand Rapids: William B. Eerdmans Publishing Company, 19

2. David, J.(1989). Hesselgrave, Edward Rommen Contextualization: Meanings, Methods, and Models (Grand Rapids: Bakers Book House, 1989), 1

3. Hill, E.V.(1992). "Cross-Cultural Preaching" in Leadership Handbook of Preaching and Worship: Practical Insights from a Cross Section of Ministry Leaders. James D. Berkley (ed)(Grand Rapids: Baker Books, 48

4. Matthew, D. (2017). Kim, Preaching with Cultural Intelligence: Understanding The People who Hear our Sermons (Grand Rapids: Bakers Publishing Group, 2017), 5

5. David Livermore, Cultural Intelligence: Master The One Skill You Can't Do Without in Today's Global Economy (New York: AMACO, 2011), 5

6. Soon, A., \& Linn, V. D. (2008). "Conceptualization of Cultural Intelligence: Definition, Distinctiveness, and Nomological Network" i $\mathrm{n}$ Handbook Of Cultural Intelligence: Theory, Measurement, And Applications Soon Ang and Linn Van Dyne (ed) (New York: M.E. Sharpe Inc., 2008), 3

7. P. Christopher Earley., \& Soon, A. (2003). Cultural Intelligence: Individual Interactions Across Cultures (Stanford: Stanford University Press, 2003), 62

8. Elizabeth, H.E. (2012). "Expatriate Success: Cultural intelligence and Personality as Predictors for cross-Cultural Adjustment" A Thesis Submitted to the University of Tennessee at Chattanooga for the Award of The Degree Master of Science in Psychology, 14.

9. David Livermore, Cultural Intelligence: Master The One Skill You Can't Do Without in Today's Global Economy, 7

10. David, L. (2010). Leading With Cultural Intelligence: The New Secret to Success (New York: AMACOM, 2010), 26

11. David Livermore, Cultural Intelligence Difference. 7

12. Matthew, D. (2017). Kim, Preaching with Cultural Intelligence: Understanding the People Who Hear Our Sermons (Grand Rapids: Baker Publishing Company, 2017), 6.

13. Joost, J. L. E. (2015). Bücker, Olivier Furrer and Yanyan Lin, "Measuring Cultural Intelligence: A New Test on the CQ Scale" Working Paper SES. University De Freiburg, No. 46: 6

14. Ibid

15. Joost J. L. E. Bücker, Olivier Furrer and Yanyan Lin, 7

16. Livermore, 7 
17. Joost J. L. E. Bücker, Olivier Furrer and Yanyan Lin,7

18. Livermore, 7

19. Joost J. L. E. Bücker, Olivier Furrer and Yanyan Lin, 7

20. Donald C. (2014). The Four D's of Preaching: Definition, Design, Delivery, Destination (N/A: Lulu.com, 25

21. Frank A.C, Mantello, Rigg A.G.(1996). Medieval Latin: An Introduction and Bibliographical Guide (Washinton D.C: Catholic University Press, 1996), 659

22. Ibid

23. Scambler, T.H. (1994). The Art of Sermon Construction (Melbourne: Austral Printing and Publishing Limited, 12

24. David, L. (1989). Larsen, Anatomy of Preaching: Identifying the Issues in Preaching Today (Grand Rapids: Kregel Publications), 131

25. Ibid, 135

26. Fred, R. (2008). Lybrand, Preaching on your Feet: Connecting God and the Audience in the Preachable Moment (Nashville: B\&H Publishing Group, 2008), 28

27. Lybrand, 29

28. Alan, J.E. (1988). "Preach to Reach: Seven Characteristics of Effective Evangelistic Preaching" (2007). Doctor of Ministry. Paper 177. http://digitalcommons.georgefox.edu/dmin/177

29. Sidney, G. (1988). The Modern Preacher and the Ancient Text: Interpreting and Preaching Biblical Literature (Grand Rapids: William B. Eerdmans Publishing Company), 15

30. Ibid

31. Donald, S. (2007). Invitation to Biblical Preaching: Proclaiming Truth with Clarity and Relevance (Grand Rapids: Kregel Publication, 2007), 10

32. Greidanus, 118

33. Sidney, G. (2001). Sola Scriptura: Problems and Principles in Preaching Historical Texts (Eugene: Wipf and Stock Publishers, 2001), 224

34. David, M. (2003). Brown, Transformational Preaching: Theory and Practice (Texas: Virtualbookworm.com Publishing, 2003), 422

35. John, S., McClure, Dale, P.(2004). Andrews, Dan P. Moseley, Ronald J. Allen, L. Susan Bond, G. Lee Ramsey Jr., Listening to Listener's: Homiletical Case Studies (St. Louis: Chalice Press, 2004), 6

36. David, L.(1989). Larsen, Anatomy of Preaching: Identifying the Issues in Preaching Today (Grand Rapids: Kregel Publications, 1989), 131

37. Ibid, 135

38. Fred, R. (2008). Lybrand, Preaching on your Feet: Connecting God and the Audience in the Preachable Moment (Nashville: B\&H Publishing Group, 2008), 28

39. Lybrand, 29

40. Martyn Lloyd J.D. (1971). Preaching and Preachers (Grand Rapids: Zondervan Publishing House, 1971), 232

41. Fasol, A. I. (1985). "Illustration in Preaching" South Western Journal of Theology Vol. 27 Spring 1985, 5

42. Matthew Mckellar, "The Use of Illustrations in Text-Driven Preaching" www.preachingsource.com

43. Alfred, P. Gibbs. (2012). The Preacher and His Preaching (Benin: Bealuahland Publications, 2012), 187

44. Dennis, M. Cahill. (2007). The shape of Preaching: Theory and Practice in Sermon Design (Grand Rapids: Bakers Books, 2007), 130

45. Haddon, R. (1980). How to Prepare and Deliver Expository Sermons: Biblical Preaching (Grand Rapids: Bakers Book House, 1980), 191

46. Kehinde, Olusanya, O. (2018). "Homiletical Ethos: Model Principle for Congregational Persuasion" Ministerial Integrity: Papers in Honour of Rev. Dr. Sunday Ayomide Fagbemi, Abraham O. Odeleye (ed) (Ibadan:KOGIAH Communication, 2018), 130

47. John, A. (1870). Broadus, On The Preparation and Delivery of Sermons (Nashville: Broadman Press, 1870), 5

48. Larsen, 47

49. Ibid, 48

50. Ibid

51. Larry, A. (2013). Samovar, Richard E. Porter, Edwin R. McDaniel, Communication Between Cultures (Boston: Wadsworth, 2013), 27

52. Thomas, G. (2007). Long, "Trends in Homiletics" Leadership Handbook of Preaching and Worship: Practical Insight from a Cross Section of Ministry Leaders James D. Berkley (Grand Rapids: Bakers Publishing, 2007), 77

53. Boobie, K. (2009). What is Culture? (Ontario: Crabtree Publication, 2009),4

54. Vijai, N. Giri. (2006). "Culture and Communication Style" The Review of Communication vol. 6(1)2006, 124.

55. http://encyclopedia.jrank.org/articles/pages/6491/Culture-and-Communication.html

56. Marieke, D.M. (2010). Global Marketing and Advertising: Understanding Cultural Paradoxes (Los Angeles: Sage Publications, 2010), 163

57. David Pederson, "Preaching Cross-Culturally" www.preaching.com

58. Matthew, D. (2017). Kim, Preaching with Cultural Intelligence (Grand Rapids: Bakers Books, 2017), 5 